Escher, A., Sørensen, K. \& Zeck, H. P. 1976: Nagssugtoqidian mobile belt in West Greenland. In Escher, A. \& Watt, W. S. (edit.) Geology of Greenland, 74-95. Copenhagen: Geol. Surv. Greenland.

Lauerma, R. 1964: On the structure and petrography of the Ipernat dome, western Greenland. Bull. Grønlands geol. Unders. 46 (also Bull. Comm. géol. Finlande 251), 88 pp.

McGregor, V. R. \& Mason, B. 1977: Petrogenesis and geochemistry of metabasaltic and metasedimentary enclaves in the Amitsoq gneisses, West Greenland. Amer. Miner. 62, 887-904.

Noe-Nygaard, A. \& Ramberg, H. 1961: Geological reconnaissance map of the country between latitudes $69^{\circ} \mathrm{N}$ and $63^{\circ} 45^{\prime} \mathrm{N}$, West Greenland. Geol. Map Grønlands geol. Unders. 1 (also Meddr Grønland 123, 5), 9 pp.

C.R.L.F.,

Department of Geology

Oxford Polytechnic,

Headington,

Oxford $O X 3 O B P$,

U.K.
R.P.H.,

Department of Geology,

Portsmouth Polytechnic,

Burnaby Road,

Portsmouth PO1 3QL,

U.K.
I.W.N.R.,
University College of Wales,
Aberystwyth,
U.K.

\title{
Field relations of some Precambrian basic dykes in the vicinity of Sukkertoppen, central West Greenland
}

\section{R. L. Friend}

Various field relations of the basic dyke swarms near Sukkertoppen have been described (Ramberg, 1948; Berthelsen \& Bridgwater, 1960; Windley, 1970) and a preliminary chronology suggested (Bridgwater et al., 1976).

The Kangâmiut dykes are noteable in that the central portion of some of the dykes has been converted into amphibolite and garnet amphibolite (Ramberg, 1948; Windley, 1970). Otherwise they appear as normal dolerites.

Within the Sukkertoppen district the most southerly dyke which displays amphibolitisation is that occurring to the north-west of Kistefjeld (fig. 20). Within this dyke the amphibolitised zone was found to be podiform and discontinuous along strike of the dyke, dying out towards en echelon terminations. This relationship was observed in other dykes further north. Therefore the development of the amphibolite is considered to be due to deformation during the emplacement of the dyke (cf. Windley, 1970) and not to multiple intrusion (Bridgwater et al., 1976). Two of the Kangâmiut dykes warrant further description. The first (A) occurs on the northern coast of Hamborgerland (fig. 20). The dyke is about $45 \mathrm{~m}$ wide and displays typical symmetrical zoning from chilled dolerite to garnet amphibolite. At the eastern side of the dyke the schistose zone has suffered later deformation as evidenced by the development of crenulation folds and associated lineation. These structures develop across the schistose fabric and folds or destroy the earlier lineation contained within the schistosity. 


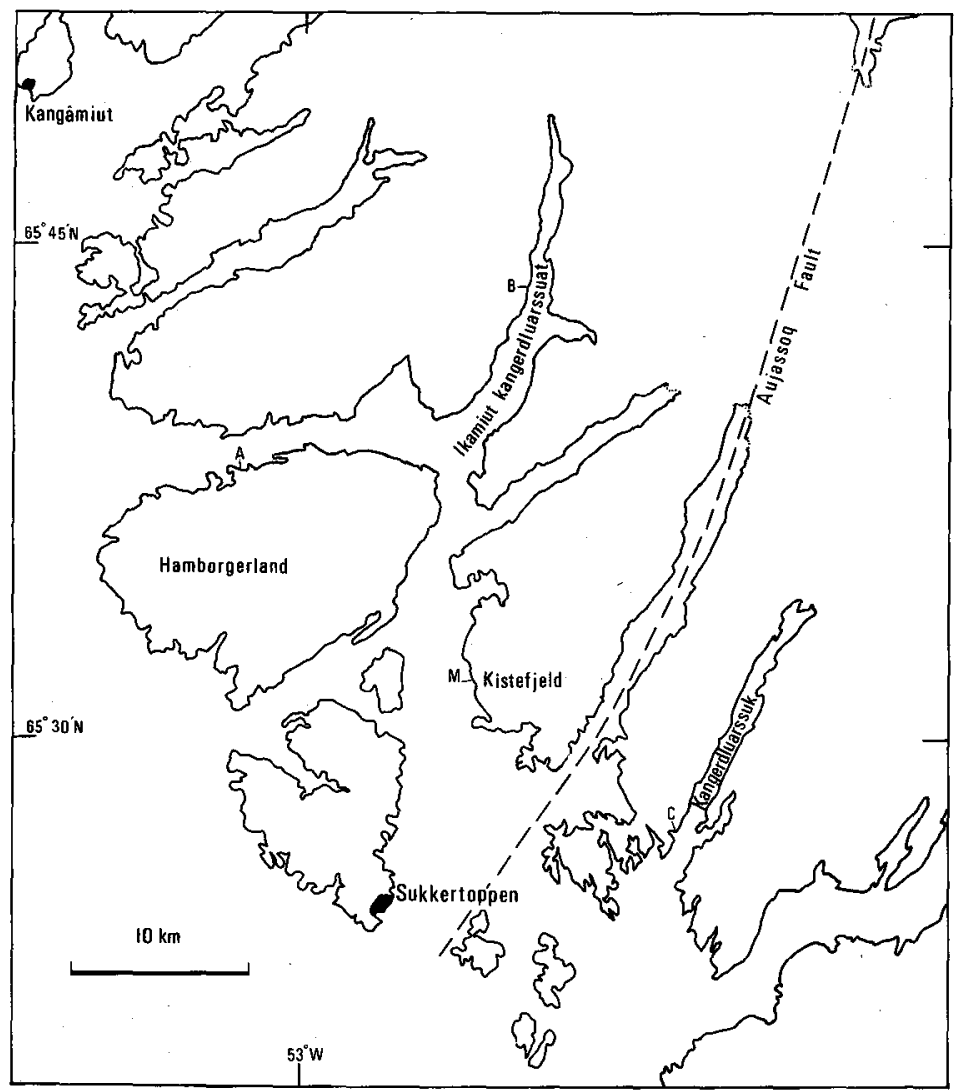

Fig. 20. Index map of the region north of Sukkertoppen showing location of features described by Friend.

The second dyke (B) outcrops along the north-west shore of Ikamiut kangerdluarssuat (fig. 20). The dyke is $10-15 \mathrm{~m}$ wide and consists of marginal zones of altered dolerite and a core zone of foliated amphibolite which is sporadically garnetiferous. The fabric of the dyke is cut by several gneissic veins which may be up to $40 \mathrm{~cm}$ thick. These are not considered to be rheomorphic veins formed by the injection of magma or the differentiation of the dyke (cf. Fahrig \& Bridgwater, 1976). The veins are sub-parallel to the foliation of the dyke and comprise two lithological types. Firstly a pinkish, fine-grained leucocratic phase and secondly a greyish, fine-grained biotite gneiss which contains small garnets. The presence of the garnet suggests that the vein may have crystallised under the same metamorphic conditions as the amphibolitised dolerite. Further brittle deformation of the dyke and gneissic veins is indicated by quartz veins which occupy sinistral shear zones which have a displacement of about $50 \mathrm{~cm}$. Up to about $10 \mathrm{~m}$ from the contact to the north-west of the dyke the gneisses show extensive retrogression from granulite facies. 
The youngest dyke swarm occurring in the Sukkertoppen area are red-brown vesicular dykes (Windley, 1970; Bridgwater et al., 1976). They are of variable thickness but usually are about $1 \mathrm{~m}$. They occupy the major joint directions which trend ESE to SE. In this area the dykes appear to be restricted to the coastal zone. Similar red dykes are found at the mouth of Ameralik fjord (McGregor, 1973) where a Tertiary age is ascribed to them (Bridgwater, 1970; Bridgwater et al., 1976). Because of their similarities a tentative correlation is suggested.

The dykes weather a distinctive red-brown, often contain xenoliths and numerous xenocrysts and display a layered structure attributable to multiple injection. The layers comprise chilled margins, vesicular and non-vesicular portions arranged in a symmetrical fashion. Xenoliths are found in many dykes but are usually less common than xenocrysts. Two dykes (C, fig. 20) occurring on the north-west shore of Kangerdluarssuk are remarkable for the number and variety of xenoliths they contain. The xenoliths may be divided into two distinct groups. Firstly, angular fragments of gneissic material locally derived and secondly, rounded to sub-rounded xenoliths of exotic derivation. Within this group there are two types of gneissic material which comprise those with granulite facies assemblages and those which are composed of glassy quartz with minor feldspar and a pale, yellow-green mineral which may include both epidote and clinopyroxene. Some of the xenocrysts consist of small glassy fragments and are considered to be derived from this type of xenolith during transportation. Secondly there are gabbroic xenoliths which consist of medium to coarse-grained amphibole and plagioclase. One of the xenocryst types consists of broken amphibole crystals, usually $5-10 \mathrm{~mm}$ long but occasionally up to $10 \mathrm{~cm}$ long. Some of the smaller crystal fragments may be derived from the gabbroic xenoliths. There are also some feldspar aggregates which may be interpreted as both phenocrysts or xenocrysts. The gabbroic xenoliths would also serve as a source for these. Thirdly there are clots of amphibole crystals which may be the source for the larger amphibole crystals and which may be related to the gabbros. Lastly there are some small, up to $5 \mathrm{~cm}$ diameter, ultrabasic xenoliths. These are of lherzolitic type containing clinopyroxene, olivine, phlogopite and a green spinel. The final xenocryst identified in the field consists of clinopyroxene fragments. These, however, are much larger than the grain size of the ultrabasic xenoliths and are of uncertain derivation.

These nodules and xenocrysts are interpreted as a sample of the lower crust through which the magma has passed and are the subject of further investigation.

\section{References}

Berthelsen, A. \& Bridgwater, D. 1960: On the field occurrence and petrography of some basic dykes of supposed Pre-Cambrian age from the southern Sukkertoppen district western Greenland. Bull. Grønlands geol. Unders. 24 (also Meddr Grønland 123, 3) 43 pp.

Bridgwater, D. 1970: A compilation of K/Ar age determinations on rocks from Greenland carried out in 1969. Rapp. Grønlands geol. Unders. 28, 47-55.

Bridgwater, D., Keto, L., McGregor, V. R. \& Myers, J. S. 1976: Archaean gneiss complex of Greenland. In Escher, A. \& Watt, W. S. (edit.) Geology of Greenland, 18-75. Copenhagen: Geol. Surv. Greenland.

Fahrig, W. F. \& Bridgwater, D. 1976: Late Archaean-early Proterozoic paleomagnetic pole positions from West Greenland. In Windley, B. F. (edit.) The Early History of the Earth, 427-439. London: John Wiley \& Son. 
McGregor, V. R. 1973: The early Precambrian gneisses of the Godthåb district, West Greenland. Phil. Trans. R. Soc. Lond. A 273, 343-358.

Ramberg, H. 1948: On sapphirine-bearing rocks in the vicinity of Sukkertoppen (West Greenland). Bull. Grønlands geol. Unders. 1 (also Meddr Grønland 142, 5) 32 pp.

Windley, B. F. 1970: Primary quartz ferro-dolerite/garnet amphibolite dykes in the Sukkertoppen region of West Greenland. In Newall, G. \& Rast, N. (edit.) Mechanism of Igneous Intrusion. Geol. J. Spec. Issue 2, 79-92.

C.R.L.F., Department of Geology, Oxford Polytechnic, Headington, Oxford $O X 3 \mathrm{OBP}$, U.K.

\section{An occurrence of ironstone enclaves east of Sukkertoppen, southern West Greenland}

\section{R. P. Hall}

Helicopter reconnaissance mapping began in 1976 in the Godthåbsfjord region (Allaart et al., 1977) progressed northwards as far as Evighedsfjord, north of Sukkertoppen during the summer of 1977 (Allaart et al., this report). Amîtsoq and Nûk type gneisses were widely recognised in the inner Godthåbsfjord region and the stratigraphy determined from coastal work by McGregor (1973) was corroborated. Friend \& Hall (1977) have described the discordant relationship of Nûk gneiss sheets to the older Amitsoq banded gneisses in the Ivisârtoq area. North of the Ataneq fault, which runs from Isua south-west into Godthåbsfjord, amphibolite horizons occur as complex interference fold structures within the predominant homogeneous, poorly foliated granitic (sensu lato) bodies such as the Taserssuaq granodiorite (Allaart et al., 1977) which are believed by the field geologists to be of Nuk age. These rocks grade into gneisses and pegmatites rich in amphibolite agmatite and/or enclaves which continue to Evighedsfjord in amphibolite to granulite facies.

A narrow horizon of rusty weathering banded ironstone enclaves was found within amphibolite-facies banded gneisses and pegmatites east of the Qardlit taserssuat lake at the north-east end of the Majorqaq moraine valley (fig. 21). This zone is $150 \mathrm{~m}$ long and is surrounded by typical amphibolite agmatitic gneisses within which the amphibolite blocks and enclaves are also locally rusty weathering. The ironstone enclaves comprise a quartz+magnetite +amphibole rock in which centimetre-scale banding is sometimes preserved, locally interleaved with thin layers of magnetite-bearing garnet quartzite. At a second locality on the $550 \mathrm{~m}$ nunatak east of the Majorqaq valley rare clinopyroxene + hornblende + garnet bearing 'quartzite' enclaves were found in which the hornblende appeared to form corona structure to pale green pyroxenes. 